\title{
Subakutní uzávěr arteria axillaris, vzniklý na podkladě embolizace z tumoru plic prorůstajícího do levé síně
}

\author{
Tomáš Paleček, Stanislav Beran, Ondřej Šmíd, Petr Mitáš* \\ II. interní klinika kardiologie a angiologie, *Il. chirurgická klinika kardiovaskulární chirurgie, Všeobecná fakultní nemocnice \\ a 1. lékařská fakulta Univerzity Karlovy, Praha, Česká republika
}

72letá kuřačka byla přijata pro několikadenní anamnézu lehké bolesti a parestezie pravé horní končetiny. Při fyzikálním vyšetření byla zjištěna absence tepenných pulsací v kubitální jamce a axile, ukazující na subakutní ischemii pravé horní končetiny. Angiografické vyšetření potvrdilo embolizační uzávěr a. axillaris 1. dx. v délce $10 \mathrm{~cm}$ (obrázek 1). Opakované pokusy o aspirační trombektomii nevedly k zprůchodnění tepny, proto byla nemocná indikována $\mathrm{k}$ urgentnímu chirurgickému řešení. Před chirurgickým výkonem bylo $\mathrm{v}$ rámci pátrání po zdroji embolizačního uzávěru provedeno transthorakální a následně jícnové echokardiografické vyšetření. Vyšetření prokázala přítomnost objemné patologické masy v levé síni, vrůstající do ní z pravé dolní plicní žíly (obrázek 2). Zároveň byla patrna výrazná patologická infiltrace plicní tkáně v těsné blízkosti levé síně. Na základě echokardiografického vyšetření bylo indikováno provedení CT hrudníku, které zobrazilo objemný tumor plic, zahrnující celý pravý dolní lalok, invadující do mediastina a vrůstající do levé síně (obrázky 3 a 4). Z toho důvodu byla stanovena diagnóza subakutního uzávěru

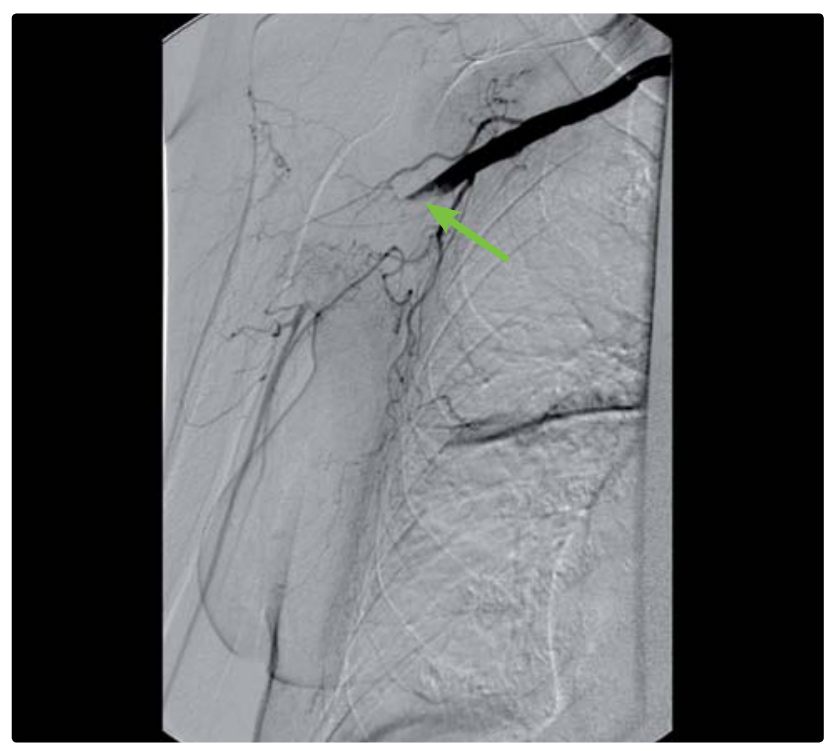

Obrázek 1 Angiografie tepen pravé horní končetiny, prokazující uzávěr a. axillaris I. dx. (šipka)

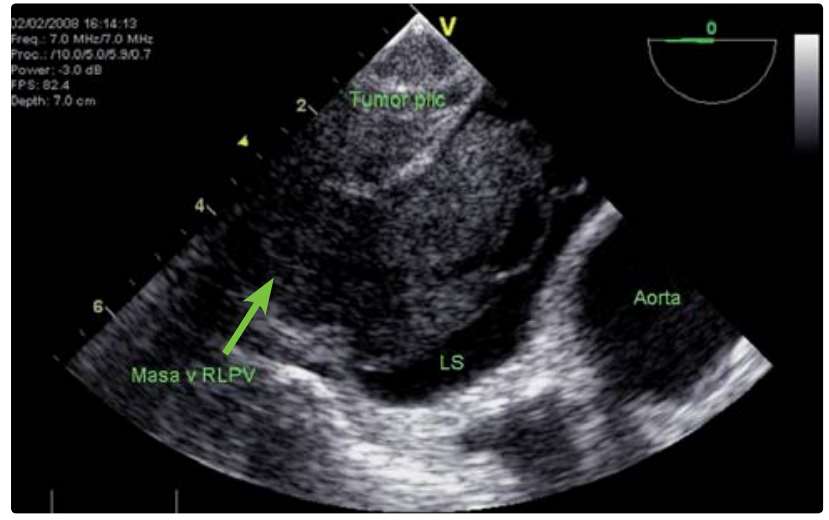

Obrázek 2 Jícnové echokardiografické vyšetření demonstrující objemnou patologickou masu prorůstající do levé síně z pravé dolní plicní žíly (RLPV); patrna je též patologická infiltrace plicní tkáně, naléhající na stěnu levé síně

a. axillaris 1 . dx., vzniklého na podkladě embolizace $\mathrm{z}$ tumoru plic prorůstajícího do levé síně. V lokální anestezii angiochirurg následně provedl úspěšnou embolektomii a. axillaris 1 . dx. Histologické vyšetření prokázalo $\mathrm{v}$ odstraněných trombotických hmotách též atypické buňky dlaždicového epitelu, které svědčily pro diagnózu dlaždicového karcinomu plic.

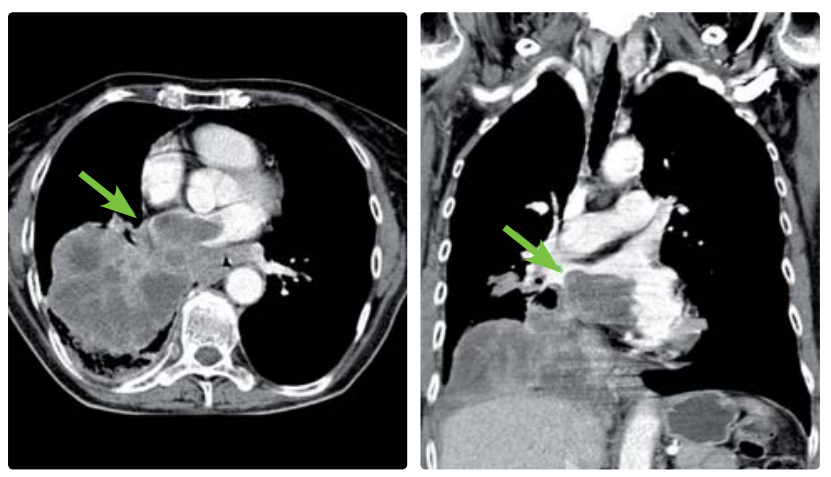

Obrázky 3 a 4 Vyšetření CT, prokazující objemný tumor pravého dolního laloku plic prorůstající do levé síně (šipky)

Adresa: MUDr. Tomáš Paleček, II. interní klinika kardiologie a angiologie, VFN a 1. LF UK, U nemocnice 2, 12808 Praha 2, Česká republika, e-mail: tpalec@lf1.cuni.cz 